Available online at http://jurnal.goretanpena.com/index.php/JSSR

\title{
IMPROVING THE STUDENTS' WRITING THROUGH TALKING STICK MODEL AT GRADE XI STUDENTS
}

\author{
Akmal \\ STMIK Royal, Kisaran \\ e-mail: akmal.shafa@gmail.com
}

\begin{abstract}
This study aimed to improve the result learn student during and to study process makes writing simple sentence through talking stick model. And students' responses toward the use of talking stick model in learning English writing. This model is expected to overcome the problem that occurs in the field. The methodology of research is classroom action research (CAR). The object of the research is students' SMK Negeri 1 Pulau Rakyat, class $\mathrm{XI}_{2}$, that amount of 30 students, academic year of 2019/2020. The classroom action research in planning, the researcher used first cycle and the second cycle. Afterwards enter cycle that first pursuant to sequence use some step that is planning, acting, observing, reflecting and the second cycle of the same steps with the first cycle. In analyzing the data the researcher used descriptive quantitative. The result of analysis assess at the first cycle showing result that the mean score 66.8, in addition, there were 6 students passed KKM in cycle I, after percent 20\%. And the second cycle showing result that mean score 86.0 in addition, there were 27 students passed KKM in cycle II, after percent $90 \%$. In this research has KKM 75. The mentioned seen from efficacy indicator indicate that study process writing simple sentence through talking stick can mount result learn students, hence this research is expressed to succeed and discontinued at the second cycle, thereby can be expressed that improving the students' writing simple sentence through talking model at grade XI students of SMK Negeri 1 Pulau Rakyat in academic year of 2019/2020, it is success
\end{abstract}

Keywords: Writing, Talking stick model

\begin{abstract}
Abstrak: Penelitian ini bertujuan untuk meningkatkan hasil belajar siswa selama dan proses pembelajaran membuat kalimat sederhana melalui model tongkat bicara. Dan tanggapan siswa terhadap penggunaan model tongkat bicara dalam pembelajaran menulis bahasa Inggris. Model ini diharapkan dapat mengatasi permasalahan yang terjadi di lapangan. Metodologi penelitian yang digunakan adalah penelitian tindakan kelas (PTK). Objek penelitian adalah siswa SMK Negeri 1 Pulau Rakyat kelas XI2 yang berjumlah 30 siswa tahun pelajaran 2019/2020. Penelitian tindakan kelas dalam perencanaan, tindakan, pengamatan, refleksi dan siklus kedua langkah yang sama dengan siklus pertama. Dalam menganalisis data peneliti menggunakan deskriptif kuantitatif. Hasil analisis penilaian pada siklus I menunjukkan hasil bahwa nilai rata-rata 66,8, selain itu terdapat 6 siswa yang lulus KKM pada siklus I, setelah persen $20 \%$. Dan siklus II menunjukkan hasil yang berarti skor 86,0 selain itu, ada 27 siswa yang lulus KKM pada siklus II, setelah persen 90\%. Dalam penelitian ini memiliki KKM 75. dari indikator kemanjuran menunjukkan bahwa proses pembelajaran menulis kalimat sederhana melalui tongkat bicara dapat meningkatkan hasil belajar siswa, maka penelitian ini dinyatakan berhasil dan dihentikan pada siklus II, dengan demikian dapat dinyatakan bahwa peningkatan pembelajaran menulis kalimat sederhana siswa melalui model berbicara pada siswa kelas XI SMK Negeri 1 Pulau Rakyat tahun pelajaran 2019/2020, berhasil.
\end{abstract}

Kata kunci: Menulis, Model Stik Berbicara 
Available online at http://jurnal.goretanpena.com/index.php/JSSR

\section{INTRODUCTION}

Language is a means of communication which is used human to interact other people in their life so that they can commnicate each other. Language consists in a speech, writing, and in a symbol so that they are able to understand the main ideas which they deliver when they are communicating. Becoming an English lecturer might be a wonderful job, especially when the lecturer is able to transfer their knowledge to the students whose English is the second language successfully (Akmal, 2019; Akmal \& Maulana, 2020; Darwish, 2016; Kasumi, 2015).

Grammar is essentials as the rules of wording to make meaningful utterances. The grammar of language is the description of the ways in which words can changed their forms and can be combined into sentences in that skill of write sentences. At least students have to master not only vocabulary but also grammar well. In this case, verbs tense have essentials role, because they tell readers, when action are taking place. Careful and accurate use of tense is important to clear write sentences. Grammar can be used to mean the study of the rules governing the use of a language (Masitoh \& Suprijadi, 2015; Pipit Rahayu., 2017; Sa 'diyah, 2017).

English role is getting more important in our life. In SMK Negeri 1 Pulau Rakyat especially at XI, they get some difficulties in learning English. According to them, English is very difficult subject because they don't understand about writing simple sentence. They find many differences in grammar in the from writing. They get difficult when use to-be and verbs in writing sentences. So, many students are wrong in writing sentences. This is can cause learning problems in SMK Negeri 1 Pulau Rakyat at grade XI. So, the writer opinions' most of the students they have problems in mastering grammar especially in writing sentences.

Tarigan expressed that writing is lower or painted symbols chart that describes a language in to understand by someone so that others can read the chart symbols if they understand language and graphic depiction of it. A person's ability in describing the graphic symbols should be understood by the author of the language itself as well as others who have a sense of the equation against the chart symbols. So the goal of writing for writing that is created can be read and understood by other people who have in common the notion of language (Tarigan 2006:21).

A sentence is a group of words that we use to communicate our ideas in writing or in speech, which has complete, independent unit of thought and consists of two main parts: a subject and a predicate. According to Furthermore, Cook (in Tarigan, 1971:2) states that a sentence is the unity of language that can stand alone relatively where it has the final intonation as well consists of clauses (Tarigan:1971). Then Kridalaksana (2001) said that a sentence is a language unit that is relatively independent, has an intonation pattern, and actually or potentially consists of clauses (Kridalaksana:2001).

The term structure in language field refers to language aspect that is signed by its role in using language. In this case, Wiyanto stated that, Although who knows the meaning of the word, does not mean he can use it in a sentence. Knowing the word and the meaning of word is important, but one word can not stand alone and can't be used in sentence in our own way. Language user should be able to construct words into a grammatical sentence. From the above statement, it can be concluded that is by mastering the sentence structure, the language users are able to understand the ideas expressed through sentences. 
Available online at http://jurnal.goretanpena.com/index.php/JSSR

\section{METHOD}

This research design was qualitative research by doing the Classroom Action Research (CAR) design (Disman et al., 2017; Grimaldo et al., 2018). the researcher took $\mathrm{XI}_{\mathrm{TKJ}}$ as the subject. The researcher chooses $\mathrm{XI}_{\mathrm{TKJ}}$ because the students in the class $\mathrm{XI}_{\mathrm{TKJ}}$ has the lowest score in write sentence, especially in write simple sentence. This class consists of 30 students.

Model in Arikunto (2009). The procedure of the Classroom Action Research (CAR) consists of four main components, namely: (1) Planning, in this step, the researcher had to prepare some planning to do this research as follow: Prepared lesson plan, defining collaboration with peers as a research partner, choose material to teach writing, prepared the observation sheet to assess how the learning condition in this class, Preparing criteria of success. (2) Action, action was step when the researcher applies the technique that had been prepared and managed into lesson plan. Generally, the activities were done in this acting were as follow: Pre-teaching activities: The teacher great to the students, the teacher checks attendance list, the teacher asks the students some question about the topic, whilst-teaching activities: In this stage, the researcher would follow some steps below: The teacher would explain to the students about what talking stick model. The students listen about explanation of material from the teacher. Giving material to the students about simple sentence. The teacher will use the talking stick model in teaching learning.

\section{FINDINGS AND DISCUSSIONS}

\section{Findings}

The learning model talking stick is one of the models of cooperative learning, the teacher gives students the opportunity to work alone and in collaboration with others in a way to optimize the participation of students and using the media a stick. The talking stick models can improve the results of student learning value, use the talking stick model of the students do not feel bored (Lie, 2002: 56).

The result indicated that there was the improvement on the students' writing achievement through talking stick model. In the first cycle the students' who got mean score 66.8 , in addition, there were 6 students passed KKM in cycle I, after percent $20 \%$. and the second cycle the students' who got mean score 86.0. in addition, there were 27 students passed $\mathrm{KKM}$ in cycle II, after percent $90 \%$. it snowed that use of talking stick model was effective because it could improve students' writing and helped English teacher to teach writing skill in the class.

Discussions

The discussion from the research as follow: Based on the problem in this research. The student's understand and can writing simple sentence through talking stick model and most student have skill correct in replying problem. The mean of observation showed that in the first cycle the students' who got mean score 66.8 , in addition, there were 6 students passed KKM, after percent $20 \%$, the students who got this score were active during the teaching learning process, though they were not so good in English. An the second cycle the students' who got mean score 86.0. in addition, there were 27 students passed KKM, after percent $90 \%$, some students' who got this score always paid attention during teaching and learning process although they are not clever, while some of them were clever and a good writing sentence so they were active in the class. 
Available online at http://jurnal.goretanpena.com/index.php/JSSR

The result observation show that the students' score from first meeting to last meeting have improved, the first cycle the students' who got mean score 66.8 , after percent $20 \%$, and the second cycle the students' who got mean score 86.0, after percent $90 \%$. it could be concluded that in the last meeting some of the students who did not active in the class but they are tried hard to learning English in writing sentence. Showed that use talking stick model was effective and make the teaching learning process more interesting and not bored. Thereby can be expressed that improving the students' writing simple sentence through talking model at grade XI students of SMK Negeri 1 Pulau Rakyat in academic year of $2019 / 2020$, it is success.

\section{CONCLUSIONS}

After analyzing the data the result of the study, the researcher found out that :

1. The students are able to write simple sentence trough talking stick model at grade XI students SMK Negeri 1 Pulau Rakyat.

2. The students' score increased during the cycle. It can be seen from the mean score in test cycle I was 66.8 and the mean score of test cycle II was 86.0.

3. Trough talking stick model can to improve the students' writing simple sentence, because talking stick model can make the students become more effective, it is also help the students to write down in a paper. In addition, the students not only successfully improving their writing, but also they are successfully build their ideas. Besides that, it can be concluded that the students were more interested and enjoyable in writing by using talking stick model.

\section{REFERENCES}

Akmal. (2019). The Developing of Communicative Language Teaching on the Speaking Skill of STMIK Royal Students. Jurnal TEKESNOS, 1(1), 1-4.

Akmal, \& Maulana, C. (2020). Communicative Approach In

Teaching English Speaking Club (ESC). Journal of Linguistics, English Teaching and Education, 1(2), 49-54.

Arikunto, s. 2009. Penelitian Tindakan

Kelas. Jakarta: Bumi Aksara.

Darwish, H. (2016). International Journal of Languages ' Education and Teaching WE COULDN, $\mathrm{T}$ COMMUNICATE IN ENGLISH , COULD WE? THE COMMUNICATIVE APPROACH PRACTICES, A CRITICAL VIEW. International Journal of Languages Education and Teaching, 4(2), 183-192.

Disman, D., Ali, M., \& Syaom Barliana, M. (2017). the Use of Quantitative Research Method and Statistical Data Analysis in Dissertation: an Evaluation Study. International Journal of Education, 10(1), 46. https://doi.org /10.17509/ije.v10i1.5566

Grimaldo, F., Marušić, A., \& Squazzoni, F. (2018). Fragments of peer review: A quantitative analysis of the literature (1969-2015). PLoS ONE, 13(2), 1-14. https://doi.org/10.1371/journal.pone. 0193148

Kasumi, H. (2015). Communicative Language Teaching and Its Impact on Students' Performance. Journal of Educational and Social Research (Italy), 5(1), 155-161. https://doi.org /10.5901/jesr.2015.v5n1s1p155

Masitoh, S., \& Suprijadi, D. (2015). Improving Students' Ability in Witing Dsecriptive Text Using Genre Based on Approach (GBA) at the Eighth Grade Students of SMP 
Available online at http://jurnal.goretanpena.com/index.php/JSSR

Islam Terpadu Fitrah Insani. Elitn Journal, 3(1), 38-52.

Pipit Rahayu., I. F. E. (2017). An Analysis of the Students' Skill in Writing Descriptive Text at the Eighth Grade of SMPN 7 Tambusai Utara. Jurnal Mahasiswa Prodi Bahasa Inggris UPP, 3(1), 1-6. https://www.neliti.

com/id/publications/109729/ananalysis-of-the-students-skill-inwriting-descriptive-text-at-the- eighth-grad

Sa 'diyah, H. (2017). Improving Students' Ability in Writing Descriptive Texts Through a Picture Series- Aided Learning Strategy. The English Teacher, XL(1993), 164-182. 